\title{
КРИМІНАЛЬНО-ПРАВОВА ХАРАКТЕРИСТИКА СТВОРЕННЯ АБО УТРИМАННЯ МІСЦЬ РОЗПУСТИ І ЗВІДНИЦТВА, ПЕРЕДБАЧЕНИХ СТ. 302 КРИМІНАЛЬНОГО КОДЕКСУ УКРАЇНИ
}

\author{
Скок О. С., Шевченко Т. В.
}

\section{ВСТУП}

Створення або утримання місць розпусти і звідництво, передбачене ст. 302 Кримінального кодексу України (далі - КК України), належить до злочинів, які суперечать нормам моралі, встановленим у цивілізованому суспільстві. Здійснення протиправних дій у сфері культурного, духовного життя суспільства та громадської моралі, моральних засад суспільства в частині задоволення статевих потреб спрямовані на порушення моралі суспільства щодо зв'язків між людьми для задоволення статевих потреб на основі особистої симпатії та усвідомлення небезпеки своїх дій винними особами, які полягають у приниженні честі та гідності, створенні загрози поширення небезпечних хвороб та аморальності. Небезпечність такого правопорушення визначається тим, що воно негативно впливає на нормальний фізичний та психічний стан людини. Окрім того, нерідко призводить до суїциду, сприяє поширенню розпусти, нівелює сімейні цінності, погіршує відносини у родині, деструктивно впливає на культурний та моральний рівень суспільства. Кількість злочинів проти моральності порівняно 3 іншими злочинами, такими як: злочини проти власності, проти житття та здоров'я особи, проти громадського порядку та іншими, становить невелику кількість. Однак, незважаючи на те, що за особливостями конструкції об'єктивної сторони ці діяння є формальними, вони несуть у собі приховану суспільну небезпеку. Так, посередництво у звідництві сприяє існуванню проституції, поширенню розпусти та аморальності в інтимних стосунках людей, поширенню венеричних та інших невиліковних хвороб. Особливо небезпечними визнаються такі дії у разі вчинення їх із залученням неповнолітніх та малолітніх.

Метою цього дослідження $є$ встановлення об'єктивних та суб'єктивних ознак злочину, передбаченого ст. 302 КК України, аналіз проблематики кримінально-правових норм, які фактично реалізують відповідальність за створення або утримання місць розпусти і звідництво.

Окремі питання кримінальної відповідальності за створення або утримання місць розпусти і звідництво розглядали у своїх роботах: О.І. Бандурка, С.В. Гринчак, І.М. Доляновська, Д.О. Калмиков, 
В.В. Кузнєцов, А.В. Ландіна, Я.Г. Лизогуб, А.А. Нєбитов, А.М. Орлеан, О.В. Пальчук, С.П. Репецький та ін. Питання кримінологічної характеристики створення або утримання місць розпусти і звідництво розглядала Т.І. Усатова та ін., криміналістичній характеристиці такого виду злочину приділяли увагу: К.Ю. Береза, О.М. Смець, Д.С. Кирюха, I.B. Сіроух та ін. Однак, незважаючи на проведені дослідження, натепер залишаються невисвітленими низка питань щодо особливостей кваліфікації діяння за ст. 302 КК України.

Поряд із чітко зазначеними критеріями визначення такого протиправного діяння є низка певних особливостей кваліфікації та призначення покарання.

\section{1. Аналіз статистичних даних України та зарубіжного досвіду окремих країн щодо кримінальної відповідальності за діяння з ознаками створення або утримання місць розпусти і звідництва}

Так, за офіційними даними Генеральної прокуратури України у 2015 році обліковано злочинів, передбачених ст. 302 КК України, - 476, притягнуто осіб до кримінальної відповідальності - 380, питома вага від загальної кількості злочинів проти громадського порядку та моральності (8 591) становила 5,5\% .

У 2016 році обліковано злочинів за ст. 302 КК України - 342, притягнуто осіб до кримінальної відповідальності - 220, питома вага від загальної кількості злочинів проти громадського порядку та моральності (7 715) становила $4,4 \%{ }^{2}$.

У 2017 році обліковано злочинів, передбачених ст. 302 КК України, 234 , притягнуто осіб до кримінальної відповідальності - 210, питома вага від загальної кількості злочинів проти громадського порядку та моральності (7 890) становила $3 \%{ }^{3}$.

У 2018 році обліковано злочинів, передбачених ст. 302 КК України, 225 , притягнуто осіб до кримінальної відповідальності - 196, питома вага від загальної кількості злочинів проти громадського порядку та моральності (8 263) становила 2,7\% ${ }^{4}$.

\footnotetext{
${ }^{1}$ Статистичні дані Генеральної прокуратури України про кримінальні правопорушення по державі за 2015 рік. URL: https://old.gp.gov.ua/ua/stst2011.html?dir_id=112169\&libid=100820\# (дата звернення: 06.05.2020).

${ }^{2}$ Статистичні дані Генеральної прокуратури України про кримінальні правопорушення по державі за 2016 рік. URL: https://old.gp.gov.ua/ua/stst2011.html?dir_id=112661\&libid=100820 (дата звернення: 07.05.2020).

${ }^{3}$ Статистичні дані Генеральної прокуратури України про кримінальні правопорушення по державі за 2017 рік. URL: https://old.gp.gov.ua/ua/stst2011.html?dir_id=113281\&libid=100820 (дата звернення: 07.05.2020).

${ }^{4}$ Статистичні дані Генеральної прокуратури України про кримінальні правопорушення по державі за 2018 рік. URL: https://old.gp.gov.ua/ua/stst2011.html?dir_id=113653\&libid=100820 (дата звернення: 08.05.2020).
} 
У 2019 році обліковано злочинів, передбачених ст. 302 КК України, 259 , притягнуто осіб до кримінальної відповідальності - 214, питома вага від загальної кількості злочинів проти громадського порядку та моральності (6 576) становила 3,9\% 5 .

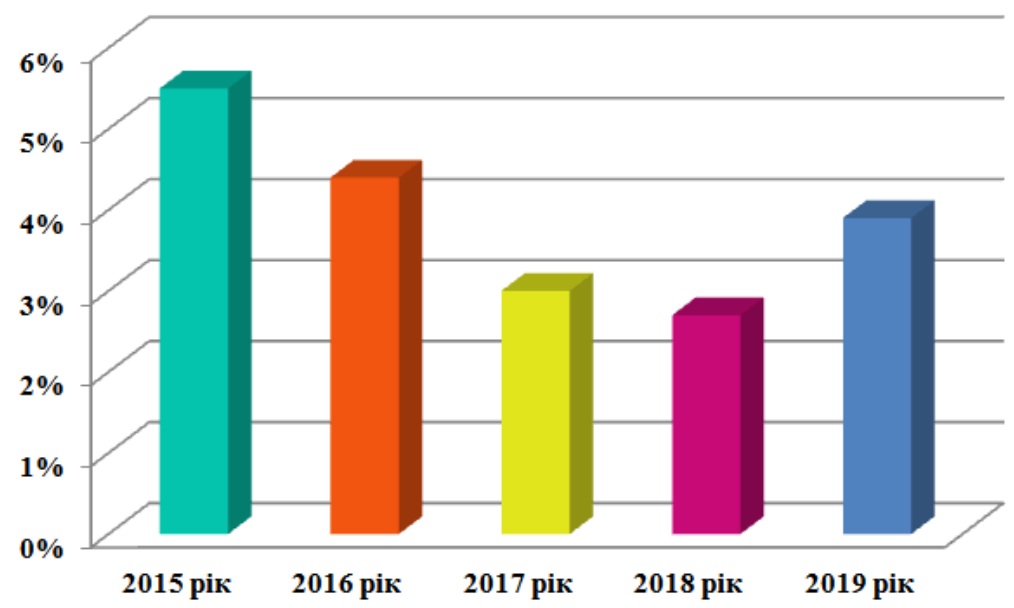

Рис. 1. Відсоткове співвідношення облікованих кримінальних правопорушень, передбачених ст. 302 КК України, за 2015-2019 pp.

Аналіз статистичних даних указує на стале зниження рівня облікованих злочинів, передбачених ст. 302 КК України, за останні п’ять років. На фоні загального зниження рівня злочинності ми можемо побачити у 2019 році збільшення питомої ваги порівняно із загальним зниженням злочинів проти громадського порядку та моральності. Однак потрібно врахувати високий рівень латентності таких злочинів, реєстрація яких відбувається лише за викриттям правоохоронними органами місць розпусти або виявлення факту звідництва.

На відміну від положень КК України в частині кримінальної відповідальності за створення або утримання місць розпусти і звідництво, ст. 241 КК Російської Федерації (далі - КК РФ) передбачає відповідальність за організацію заняття проституцією. Така норма регламентує діяння, спрямовані на організацію заняття проституцією іншими особами, а також утримання місць розпусти для заняття проституцією або систематичне надання приміщень для заняття проституцією. Щодо кваліфікуючих ознак, то ними можуть бути такі: вчинення діяння особою з використанням свого

\footnotetext{
${ }^{5}$ Статистичні дані Генеральної прокуратури України про кримінальні правопорушення по державі за 2019 рік. URL: https://old.gp.gov.ua/ua/stst2011.html?dir_id=113897\&libid=100820 (дата звернення: 08.05.2020).
} 
службового становища; із застосуванням насильства або з погрозою його застосування; 3 використанням для заняття проституцію неповнолітніх; 3 використанням для заняття проституцією осіб, які не досягли чотирнадцятирічного віку. Серед переліку покарань, передбачених санкціями ч. ч. 1-3 ст. 241 КК РФ, є штраф у розмірі від ста тисяч до п'ятисот неоподатковуваних мінімумів доходів громадян або в розмірі заробітної плати або іншого доходу засудженого за період від одного року до трьох років, або примусові роботи на строк до п'яти років, або позбавлення волі на той самий строк (ч. 1 ст. 241 КК РФ); позбавлення волі на строк до шести років з позбавленням права обіймати певні посади чи займатися певною діяльністю на строк до десяти років або без такого та 3 обмеженням волі на строк до двох років або без такого (ч. 2 ст. 241 КК РФ); позбавлення волі на строк від трьох до десяти років 3 позбавленням права обіймати певні посади чи займатися певною діяльністю на строк до п'ятнадцяти років або без такого та з обмеженням волі на строк від одного року до двох років або без такого (ч. 3 ст. 241 КК РФ) ${ }^{6}$.

Кримінальний кодекс Республіки Казахстан (далі - КК РК) у ст. 309 встановлює відповідальність за організацію або утримання місць розпусти для заняття проституцією і звідництво. Так, організація або утримання місць розпусти для заняття проституцією, а також звідництво з корисною метою карається позбавленням волі на строк до п'яти років з конфіскацією майна. При цьому ч. 2 ст. 309 КК РК передбачає вчинення такого злочину групою осіб за попередньою змовою; неодноразово; поєднане із залученням неповнолітнього в заняття проституцією, за що санкцією ч. 2 ст. 309 передбачено покарання у вигляді позбавлення волі на строк від трьох до семи років 3 конфіскацією майна. Найсуворіше покарання у вигляді позбавлення волі на строк від п'яти до десяти років з конфіскацією майна встановлено в санкції ч. 3 ст. 309 КК РК за скоєння визначених вище діянь злочинною групою ${ }^{7}$.

\section{2. Об'сктивні ознаки створення або утримання місць розпусти і звідництва}

Відповідно до ст. 2 «Конвенції про боротьбу з торгівлею людьми і 3 експлуатацією проституції третіми особами» від 2 грудня 1949 р. сторони цієї Конвенції зобов'язуються накладати покарання на кожного, хто: а)

\footnotetext{
${ }^{6}$ Кримінальний кодекс Російської Федерації : Закон Російської Федерації від 13.06.1996 р. № 63-Ф3. Дата оновлення: 12.04.2020 p. URL: http://www.consultant.ru/document/cons_doc_LAW_10699/ (дата звернення: 10.05.2020).

${ }^{7}$ Кримінальний кодекс Республіки Казахстан : Закон Республіки Казахстан від 03.07.2014 р. № 226-V. Дата оновлення: 04.05.2020 p. URL: https://online.zakon.kz/document/?doc_id=31575252 (дата звернення: 12.05.2020).
} 
утримує будинок розпусти чи управляє ним або свідомо фінансує, чи бере участь у його фінансуванні; б) здає в оренду або наймає будівлю чи інше місце, або його частину, знаючи, що вони будуть використані з метою проституції третіми особами. Слід зазначити, що зміст ст. 302 КК України повністю відповідає основним положенням цієї Конвенції.

Диспозиція ч. 1 ст. 302 КК України викладена як створення або утримання місць розпусти, а також звідництво для розпусти. Суспільна небезпечність злочину полягає в тому, що дії, які його утворюють, посягають на основні засади суспільної моральності у сфері статевих відносин. Стаття 7 Конвенції передбачає, що вироки, винесені раніше в інших державах за утримання будинків розпусти чи управління ними, або фінансування беруться до уваги, оскільки це допускається внутрішнім законодавством, для встановлення факту рецидивізму ${ }^{8}$.

Суспільна небезпека злочину, передбаченого ст. 302 КК України, полягає в тому, що дії, які його утворюють, сприяють поширенню розпусти та аморальності в статевих відносинах людей; перетворюють жінку (чоловіка) на знаряддя задоволення статевої втіхи як з їі (його) згоди, так і з використанням певних життєвих обставин; сприяють поширенню венеричних та інших інфекційних захворювань; ведуть до деградації неповнолітніх; є засобом незаконного отримання прибутку та одним із злочинів, на яких спеціалізуються організовані злочинні об'єднання; має великий рівень латентності; негативно впливає на нормальний моральний розвиток особи, статеве виховання неповнолітніх; сприяє вчиненню інших злочинів (проти життя та здоров'я особи, проти волі, честі та гідності особи, проти статевої свободи та недоторканості особи тощо $)^{9}$.

Безпосереднім об'єктом злочину є суспільні відносини, що забезпечують основні принципи суспільної моралі у сфері статевих відносин. Саме моральна сторона злочину, яка передбачає надання платних і безоплатних послуг сексуального характеру між особами різної або однієї статі, незнайомими між собою або малознайомими, заняття проституцією. Особливо, що стосується надання таких послуг неповнолітніми або малолітніми особами. Такі дії призводять до поширення сексуальної розбещеності та втрати моральності.

\footnotetext{
${ }^{8}$ Конвенція про боротьбу з торгівлею людьми і 3 експлуатацією проституції третіми особами : Міжнародний документ від 02.12.1949. URL: https://zakon.rada.gov.ua/laws/show/995_162 (дата звернення: 05.05.2020).

9 Нєбитов А.А. Кримінальна відповідальність за створення або утримання місць розпусти і звідництво: актуальні проблеми теорії і практики. Боротьба з організованою злочинністю $і$ корупиією (теорія і практика). 2014. № 1 (32). С. 95-98.
} 
Потерпілими від злочину можуть бути неповнолітні або малолітні особи, які добровільно залучалися до вчинення розпусних дій, у частині спричинення фізичної або моральної шкоди, а також спричинення шкоди психічному здоров'ю та нормальному розвитку. Що стосується малолітньої особи (ч. 4 ст. 302 КК України), то такі особи через свій вік (до 14 років) не могли повною мірою розуміти характер надання ними послуг.

3 об'єктивної сторони цей злочин полягає у виконанні однієї 3 перелічених дій: створенні місць розпусти; утриманні місць розпусти; звідництві для розпусти.

Створення місця розпусти - це не обов'язково будівництво в прямому значенні архітектурної конструкції, призначеної для можливості перебування в приміщенні, а завершений пошук приміщення чи іншого місця, відкриття закладу (масажний салон, сауна), під яким маскується місце розпусти, облаштування такого місця, підбір обслуговуючого персоналу, забезпечення засобами зв'язку, транспорту. Утримання місця розпусти означає вчинення дій, що забезпечують його використання та функціонування. Утримання місця розпусти передбачає, наприклад, пошук клієнтів, оплату оренди приміщення, транспорту, інші фінансові розрахунки, придбання i реалізацію для клієнтів білизни, напоїв, продуктів, рекламу тощо. В теорії кримінального права чітке визначення поняття «звідництво» відсутнє. Звідництво - це своєрідне посередництво, що виявляється у сприянні добровільним сексуальним відносинам незнайомих між собою осіб. Воно може полягати у знайомстві або організації зустрічей таких осіб, у пошуку осіб, які згодні займатися розпустою, у схилянні осіб до розпусти та ін. ${ }^{10}$.

При цьому варто зазначити, що кількісна ознака вказаних дій законодавцем не визначена, як і ознака систематичності, натомість явно виражена часова ознака. Наприклад, утримання місця розпусти передбачає тривалість, тобто злочин одиничний триваючий. Суб'єкт злочину, який утримує місце для розпусти, постійно перебуває в стані скоєння злочину до моменту припинення своїх злочинних діянь з власної волі або викриття існування такого місця.

Створення або утримання місць розпусти у теорії кримінального права визначено таким чином, що відсутні чіткі критерії відмежування одного діяння від іншого. Тому створенням місць розпусти слід вважати будь-які дії, що призвели до виникнення такого місця. Водночас утримання місця $\epsilon$ більш небезпечним, оскільки пов'язане з тривалим його функціонуванням. Отже, утримання місця пропонуємо визначити як забезпечення можливості

\footnotetext{
${ }^{10}$ Кримінальне право України : Особлива частина : підручник / Ю.В. Баулін та ін. ; за ред. В.В. Сташиса, В.Я. Тація. Харків : Право, 2010. 608 с.
} 
одній чи декільком особам відвідати його два і більше разів. Тобто 3 моменту другого використання одного й того самого місця відвідувачами протиправні дії слід кваліфікувати як утримання місць розпусти ${ }^{11}$.

Місцем розпусти визнається будь-яке приміщення або інше місце, спеціально підготовлене чи пристосоване для постійного або періодичного вчинення розпусних дій невизначеним колом осіб, або постійними відвідувачами, які змінюють партнерів. Таке місце призначене для заняття проституцією, еротичного масажу, інших послуг сексуального характеру, спрямованих на задоволення статевих потреб. Ним може бути будинок, квартира, кімната в гуртожитку, номер у готелі, офіс, намет, підсобні приміщення, що використовуються для розпусних дій.

Так, наприклад, Шевченківський районний суд м. Києва встановив, що в період з серпня 2015 року по 17.08.2017 року (момент викриття існування місць розпусти) дві особи, діючи спільно 3 корисливих мотивів, 3 метою особистого збагачення, переслідуючи мету, спрямовану на створення i утримання місць розпусти та звідництва 3 метою наживи, а також сутенерства, створили три місця розпусти під виглядом масажних салонів.

Надалі, розподіливши між собою функції, до яких входять: пошук, вибір та забезпечення діяльності приміщень масажних салонів, пошук клієнтів та жінок для надання послуг сексуального характеру, звідництво останніх, рекламування послуг, маючи чітко визначені ролі кожного учасника, єдиний план, в якому передбачено розподіл функцій учасників групи, почали існувати як злочинна група. Таким чином, у створених місцях розпусти постійно перебували жінки, які надавали послуги сексуального характеру. До сексуальних послуг входили еротичний масаж, масаж для сімейної пари, масаж за участю двох жінок, також існувала програма на дві години, крім цього, у вказаних салонах надавались послуги орального сексу. На дзвінки клієнтів, які телефонували на рекламні номери, відповідали жінки-оператори, які працювали позмінно в орендованій квартирі ${ }^{12}$.

За зазначених умов наявні ознаки організованої групи, передбачені ч. 3 ст. 28 КК України, а саме: кількісна ознака - три і більше осіб, попередня стійка організація, про що говорить тривале існування у період з 2015 по 2017 роки, об'єднані єдиним планом та розподіл функцій учасників групи для досягнення єдиної мети - отримання постійного фінансового прибутку

11 Нєбитов А.А. Кримінальна відповідальність за створення або утримання місць розпусти i звідництво: актуальні проблеми теорії і практики. Боротьба з організованою злочинністю $і$ корупцією (теорія і практика). 2014. № 1 (32). С. 95-98.

${ }^{12}$ Вирок Шевченківського районного суду м. Києва від 20.02.2019 року. Справа № 761/21298/18. Провадження № 1-кп/761/1306/2019. URL: http://reyestr.court.gov.ua/Review/79986540 (дата звернення: 20.05.2020). 
від створення, утримання місць розпусти та звідництва (посередництва) між замовниками та особами, які добровільно надають послуги інтимного характеру за грошову винагороду. Розподіл отриманого прибутку здійснювався між учасниками групи. У вироку така форма співучасті визначена як злочинна група, а не організована група. Беручи до уваги факт притягнення до кримінальної відповідальності лише однієї особи, яка виконувала функції оператора і не була організатором, однак знала про злочинну діяльність та на постійній основі отримувала прибуток, тому $\epsilon$ учасником організованої групи i повинна нести кримінальну відповідальність за звідництво для розпусти з метою наживи та вчинене членом організованої групи діяння.

Що стосується звідництва для розпусти, то варто зазначити про кількісну ознаку. Злочин вважається закінченим з моменту звідництва, тобто досить лише вчинення однієї дії. Однак, як показує судова практика, більшість злочинів вчиняється декілька разів, при цьому кваліфікуюча ознака повторності в диспозиції статті відсутня. Сама норма представлена як так званий ускладнений одиничний злочин, а саме продовжуваний.

Продовжуваний злочин характеризується вчиненням суб'єктом злочину декількох тотожних за своєю суттю діянь, спрямованих на досягнення загальної мети, тобто таких, які охоплюються єдиним умислом i становлять у сукупності один одиничний злочин. Продовжуваний злочин вчиняється не одразу, а певними «порціями» 13 .

Початком продовжуваного злочину треба вважати вчинення першого 3 числа декількох тотожних діянь; закінченням - момент вчинення останнього із задуманих злочинних діянь, тобто досягнення мети, до якої прагнув винний. Продовжуваний злочин вважається закінченим з моменту доведення суб'єктом свого злочинного наміру до кінця.

Тобто наявність єдиної мети для вчинення декількох тотожних дій повинна бути обов'язковою. Постає питання, чи можна розглядати як мету розпусту? Очевидно, що ні. Однак наявність мети для ч. 1 ст. 302 КК України не $\epsilon$ обов'язковою ознакою. Для правильної відповідності необхідно вказати в диспозиції статті спеціальну мету для звідництва, наприклад, наживу. Лише за цих обставин можна розглядати звідництво як одиничний продовжуваний злочин, який буде складатися 3 декількох тотожних діянь, вчинених з єдиною метою у вигляді отримання наживи або встановити як кваліфікуючу ознаку вчинення звідництва для розпусти - повторність.

\footnotetext{
13 Александров Ю.В., Клименко В.А. Кримінальне право України: Заг. Частина : підручник для студентів вищих навчальних закладів. Київ : МАУП, 2004. 328 с.
} 
Так, Шевченківським районним судом м. Запоріжжя було встановлено, що громадянин обвинувачується у тому, що в період з 22.03.2016 року по 05.04.2016 року займався звідництвом для розпусти, вчиненим з метою наживи, суть якого полягала в посяганні на моральні засади суспільства в частині задоволення сексуальних потреб окремих осіб, встановленні зв'язків між людьми за грошову винагороду для задоволення їхніх статевих пристрастей, що проявлялося в організації безладних статевих контактів, із встановленням ведення статевого життя виключно за винагороду, незважаючи на особисту симпатію зведених для цього осіб, сприянні проституції. Зокрема, зазначене звідництво проявлялося у підшукуванні та отриманні обвинуваченим замовлень від чоловіківклієнтів, які потребували оплатних сексуальних послуг, залученні жінок, які займаються проституцією та організацією їхніх зустрічей для задоволення статевих потреб клієнтів.

Так, 22.03.2016 року обвинувачений одержав замовлення на отримання оплатних сексуальних послуг із подальшим досягненням мети звідництва для розпусти, виступаючи посередником шляхом підшукування учасників розпусних дій, запропонував особі вступити у статевий зв'язок 3 його знайомою, яка займалася проституцією, за що отримав грошову винагороду у розмірі 50 гривень. Так, продовжуючи свою злочинну діяльність обвинувачений вчинив ті самі дії з розривом у часі 25.03.2016 року та 05.04.2016 року ${ }^{14}$.

Тож, ми можемо визначити наявність кваліфікуючої ознаки повторності, хоча суд робить вказівку на продовження злочинної діяльності, i кваліфікація відбувається за ознакою спеціальної мети - наживи. Частина 2 статті 302 КК України передбачає лише наявність спеціального рецидиву, тобто вчинення злочину особою, яка раніше була судима за цей злочин. Таким чином, імплементовано норми згаданої Конвенції щодо обтяження покарання осіб лише раніше судимих за створення або утримання місць розпусти і звідництво для розпусти. Доцільно в диспозиції статті вказати на кількісну ознаку систематичності звідництва, що передбачає вчинення дій однакового характеру три і більше разів.

\section{3. Суб'сктивна сторона створення або утримання місць розпусти і звідництва}

Суб'єктивна сторона злочину характеризується прямим умислом, тобто особа усвідомлює суспільно небезпечний характер вчинюваних нею дій

\footnotetext{
${ }^{14}$ Вирок Шевченківського районного суду м. Запоріжжя від 05.04.2019 р. Справа № 336/3804/16-к. Провадження № 1-кп/336/13/2019. URL: http://reyestr.court.gov.ua/Review/80961270 (дата звернення: 20.05.2020).
} 
щодо створення або утримання місць розпусти і звідництва для розпусти i бажає так діяти. Мотив та мета на кваліфікацію не впливають, однак за наявності мети наживи дії винного підлягають кваліфікації за ч. 2 ст. 302 КК України. Повертаючись до поняття «звідництво», яке передбачає корисливе посередництво між двома особами для вчинення дій сексуального характеру, слід зазначити, що тлумачний словник української мови визначає звідництво як: корисливе посередництво між чоловіком і жінкою для налагодження між ними любовних стосунків ${ }^{15}$. Знову ж таки постає питання кількісної ознаки. Так, злочин вважається закінченим 3 моменту виконання будь-якої 3 перелічених дій, а так само 3 моменту звідництва, достатнього лише одноразово, всі інші випадки потребують окремої кваліфікації або вказівки на повторність, відсутньої як кваліфікуючої ознаки.

Дії, вчинені з метою наживи, визнаються у разі наявності у винного наміру отримати матеріальну винагороду у будь-якому вигляді, наприклад, шляхом вчинення чи участі у вчиненні таких дій ухилитися від сплати боргу або інших сум, які він повинен був сплатити. Тому мета наживи має місце і тоді, коли з якої-небудь причини обіцяна винагорода за вчинену дію не була отримана.

Як зазначає А. Орлеан, дії, передбачені ч. 1 ст. 302 КК України, не можна вважати експлуатацією, оскільки вони не охоплюють наявність корисливого мотиву. Проте доцільність існування та правильність побудови такої кримінально-правової заборони мають бути грунтовно перевірені. Складно не помітити, що вчинене без мети наживи звідництво не має достатнього для криміналізації ступеня суспільної небезпечності. Адже в сучасних умовах розвитку суспільства, коли відбулась так звана сексуальна революція, посередництво в знайомстві людей, які мають на меті подальші стосунки (в тому числі й сексуальні), не вважається суспільно небезпечним ${ }^{16}$.

Так, Дружківський міський суд Донецької області встановив, що 25 травня 2016 року обвинувачена працевлаштувалась адміністратором готельного комплексу, до якого приїхав раніше не знайомий їй громадянин та поцікавився у останньої про можливість замовлення готельного номера та викликом у номер дівчини на його смак, з певними зовнішніми даними, для надання послуг сексуального характеру за грошову винагороду. Вислухавши побажання клієнта, у обвинуваченої раптово виник умисел на звідництво для розпусти шляхом посередництва у вигляді знайомства та

\footnotetext{
${ }^{15}$ Словник української мови : в 11 томах / ред. Г.М. Гнатюк, Т.К. Черторизька. Київ : Наукова думка, 1972. Том 3. $744 \mathrm{c}$.

${ }^{16}$ Орлеан А. Кримінально-правова охорона людини від сексуальної експлуатації. Вісник Національної академї̈ прокуратури Украӥни. 2012. № 2. С. 5-54.
} 
організації зустрічі раніше не знайомого їй громадянина 3 особою, яка займається розпустою, для сприяння добровільним інтимним стосункам між ними, після чого остання прийняла замовлення на користування номером готелю від громадянина та погодилась на прохання останнього організувати йому зустріч для надання сексуальних послуг з особою, яка займається розпустою.

Надалі обвинувачена, діючи умисно, достовірно усвідомлюючи суспільно небезпечний характер своїх дій, які посягають на суспільні відносини, що забезпечують основні засади суспільної моральності у сфері статевих відносин, переконавшись у платоспроможності громадянина, зв'язалась з особою, яка займалась сутенерством у містах Краматорську, Дружківка та Костянтинівка, повідомивши останній про бажання відвідувача готелю отримати послуги сексуального характеру, його платоспроможності та необхідності прибуття до вказаного готельного комплексу жінки легкої поведінки худорлявої статури. Після отримання згоди на прибуття повії на виклик обвинувачена провела громадянина до приміщення, замовленого ним готельного номера, куди прибула особа, яка займається розпустою, обвинувачена, сприяючи добровільним сексуальним стосункам незнайомих осіб між собою, повідомила останній номер кімнати, у якій ії чекає «клієнт».

Надалі за безпосереднього сприяння адміністратора готельного комплексу в приміщенні кімнати готелю були надані послуги сексуального характеру за грошову винагороду у розмірі 600 гривень. Дії обвинуваченої органом досудового розслідування кваліфіковані за ч. 1 ст. 302 КК України як звідництво для розпусти ${ }^{17}$.

Таким чином, дії винної особи кваліфіковані без ознаки наживи, що за наведених обставин викликає сумніви. Позаяк нажива передбачає не лише безпосередню передачу грошових коштів від клієнта, сутенера та інших осіб, а й отримання, наприклад, премії від керівництва готелю за задоволення бажань клієнта. Тому, погоджуючись 3 цією думкою, можемо зазначити, що в диспозиції ст. 302 КК України обов'язковою ознакою необхідно зазначити мету наживи.

Варто звернути увагу на випадки, коли не встановлена спеціальна мета наживи. Так, Довгинцівський районний суд м. Кривого Рогу Дніпропетровської області встановив, що обвинувачений домовився із громадянами, які надають сексуальні послуги за грошову винагороду, про підшукування для цих цілей чоловіків-клієнтів для сприяння добровільним

\footnotetext{
${ }^{17}$ Вирок Дружківського міського суду Донецької області від 06 вересня 2018 року. СУН 229/3234/17. Провадження 1-кп/229/130/2018. URL: http://reyestr.court.gov.ua/Review/76365933 (дата звернення: 20.05.2020).
} 
інтимним стосункам між ними. Продовжуючи реалізацію свого злочинного наміру, спрямованого на звідництво для розпусти, сприяючи добровільним сексуальним стосункам незнайомих між собою осіб, приблизно о 18:50 21.08.2018 року обвинувачений зустрів третю особу і провів його до приміщення кімнати, яка розташована в квартирі, де познайомив з однією 3 осіб, які надають сексуальні послуги, на що третя особа виявила бажання вступити в інтимні стосунки 3 останньою, i передала ій грошову винагороду в сумі 400 гривень за подальше надання послуг сексуального характеру. Надалі в результаті злочинних дій обвинуваченого, а саме звідництва, третій особі було добровільно надано послуги сексуального характеру за грошову винагороду. У судовому засіданні обвинувачений винним себе у вчиненні кримінального правопорушення, передбаченого ч. 1 ст. 302 КК України, визнав повністю. Суд ухвалив визнати винним у вчиненні кримінального правопорушення, передбаченого ч. 1 ст. 302 КК України, та призначив покарання у вигляді штрафу в розмірі п'ятдесяти неоподатковуваних мінімумів доходів громадян, що дорівнює 850 грн $^{18}$.

Таким чином, не підтверджений факт передачі грошової винагороди за звідництво не враховано судом як наявність спеціальної мети наживи. Крім того, судом не врахована обставина створення місця розпусти, а саме спеціально орендована квартира для здійснення розпусних дій. Тому кваліфікація за ч. 1 ст. 302 КК України дала підстави для застосування більш м'якого покарання за вчинене діяння.

Суб’єкт злочину - загальний, будь-яка особа, яка досягла 16 років. У разі вчинення цього злочину службовою особою з використанням влади чи свого службового становища іiі дії підлягають кваліфікації за сукупністю статей 302 і 364 КК України. Додаткової кваліфікації за втягнення неповнолітніх у злочинну діяльність (ст. 304 КК України) не потрібно. Однак у разі залучення до вчинення зазначених дій осіб, які не досягли 16-річного віку, або вчинення щодо них розпусних дій відповідальність повинна наставати за сукупністю - ч. 3 ст. 302 КК України і відповідною частиною ст. 156 КК України (п. 16 ППВСУ від 27 лютого 2004 р. № 2).

Друга кваліфікуюча ознака має місце у разі вчинення цього злочину особою, яка раніше була судима за такий злочин, за умови, що судимість не знята і не погашена.

На думку А.А. Нєбитова, ч. 2 ст. 302 КК України доцільно доповнити такою кваліфікуючою ознакою, як вчинення злочину групою осіб за попередньою змовою, а у ч. 3 цієї статті встановити особливо

\footnotetext{
18 Вирок Довгинцівського районного суду м. Кривого Рогу Дніпропетровської області від 06.09.2019. Справа № 211/4106/18. URL: http://reyestr.court.gov.ua/Review/84096132 (дата звернення: 21.05.2020).
} 
кваліфікуючу обставину - скоєння злочину організованою групою. Повторність злочинів, передбачених ст. 302 КК України, варто розширити повторністю злочинів, не пов'язаною із засудженням за раніше скоєний злочин і повторністю однорідних злочинів ${ }^{19}$.

Третя кваліфікуюча ознака - це вчинення дій, передбачених ч. 1 ст. 302 КК України, організованою групою.

Частина 3 ст. 302 КК України передбачає кримінальну відповідальність за вчинення дій, передбачених ч. 1 та 2 з використанням неповнолітнього. У 2018 році статтю було доповнено ще однією кваліфікуючою ознакою (частина 4) з використанням малолітнього, що є особливо кваліфікуючою ознакою.

\section{ВИСНОВКИ}

Об’єктивність цього дослідження заснована на проведеному аналізі 10 вироків судів України, зафіксованих в Єдиному державному реєстрі судових рішень, за кримінальною формою судочинства, які належать до категорії кримінальних справ «Злочини проти громадського порядку та моральності», «Створення або утримання місць розпусти або звідництво», передбачених ст. 302 КК України. На підставі такого дослідження було встановлено, що у жодному вироку не зроблено посилання на множинність злочинів, а саме відсутні сукупність, повторність та рецидив злочинів. Однак усі розглянуті вироки вказують на два або три окремі епізоди вчинених тотожних діянь, які підпадають під ознаки об'єктивної сторони злочину. Це вказує на те, що в теоретичній частині наявність спеціального рецидиву (ч. 2 ст. 302 КК України) не $є$ достатнім, а тому потрібно додати як кваліфікуючу ознаку вчинення таких дій повторно, а спеціальний рецидив визначити як особливо кваліфікуючу ознаку.

Крім того, диспозиція ст. 302 КК України не передбачає наявності спеціальної мети наживи, однак, як показує практика, всі діяння, створення, утримання або звідництво вчинені лише з метою наживи, тому необхідно додати до ч. 1 ст. 302 КК України спеціальну мету - наживу. Окрім зазначеного, також вбачаємо доцільним доповнити диспозицію «для розпусти або заняття проституцією».

Слід звернути увагу на важливий момент, який безпосередньо стосується фактично призначених покарань за досліджуваний злочин. Так, покарання у вигляді позбавлення волі строком два роки було призначено у 6 вироках; покарання у вигляді позбавлення волі строком три роки було

\footnotetext{
19 Нєбитов А.А. Кримінальна відповідальність за створення або утримання місць розпусти i звідництво: актуальні проблеми теорії і практики. Боротьба з організованою злочинністю $і$ корупиією (теорія і практика). 2014. № 1 (32). С. 95-98.
} 
призначено у 2 вироках; покарання у вигляді обмеження волі строком на два роки в 1 випадку; покарання у вигляді штрафу в розмірі п’ятдесяти неоподатковуваних мінімумів доходів громадян, що дорівнює 850 (вісімсот п’ятдесяти) гривням 00 копійок у 1 вироку. При цьому у всіх випадках, окрім призначення покарання у вигляді штрафу, осіб було звільнено від відбування покарання на підставі ст. 75 КК України. Зокрема, звільнення від покарання з іспитовим строком на 1 рік було застосовано у випадках призначення покарання у вигляді позбавлення волі на 2 роки; іспитовий строк 1 рік 6 місяців застосовано до особи, якій було призначено покарання у вигляді обмеження волі; іспитовий строк 2 роки - особам, яким призначено покарання у вигляді позбавлення волі на 3 роки.

Аналіз статистичних даних за останні п'ять років (2015-2019 роки) показав стале зниження рівня облікованих злочинів за ст. 302 КК України та кількості притягнених до кримінальної відповідальності осіб.

У частині регламентації відповідальності за діяння, які містять ознаки створення або утримання місць розпусти і звідництва, слід зазначити, що вітчизняний закон про кримінальну відповідальність встановлює доволі м'які межі покарань за цей злочин порівняно з іншими країнами. Цікавим та доречним видається досвід щодо обов'язкового застосування конфіскації майна у разі вчинення будь-якого зі складів злочинів, передбачених ст. 309 КК РК. Санкція ч. 1 ст. 302 КК України одним 3 альтернативних видів покарань пропонує штраф у розмірі до 50 неоподатковуваних мінімумів доходів громадян, що у гривневому еквіваленті становить 850 грн, на нашу думку, $є$ занадто лояльним, 3 огляду на те, що сам факт створення або утримання місць розпусти, а також звідництво для розпусти вже вчиняється задля реалізації мети наживи, хоча як така вона не передбачена диспозицією ч. 1 ст. 302 КК України.

Таким чином, на нашу думку, диспозиція статті 302 КК України повинна бути викладена в такому вигляді:

1) створення або утримання місць для розпусти або заняття проституцією, а також звідництво для розпусти або заняття проституцією 3 метою наживи;

2) ті самі дії, вчинені повторно або групою осіб;

3) дії, передбачені частиною першою або другою цієї статті, вчинені із залученням неповнолітнього або особою, раніше судимою за цей злочин, а так само вчинені організованою групою;

4) дії, передбачені частиною першою або другою цієї статті, вчинені із залученням малолітнього. 


\section{АНОТАЦІЯ}

У статті розглянуто проблемні питання та особливості кваліфікації створення або утримання місць розпусти і звідництва. 3 цією метою розглянуті об’єктивні ознаки складу злочину, передбаченого ст. 302 Кримінального кодексу України. Проведений аналіз статистичних даних, облікованих за останні п'ять років (2015-2019 роки) за ст. 302 КК України. Детально розглянуто поняття створення, утримання місць розпусти та окремо визначення звідництва для розпусти. Приділено увагу множинності для кваліфікації та кваліфікуючої ознаки - спеціальному рецидиву, передбаченому ч. 2 ст. 302 КК України. Також 3'ясовано визначення наявності спеціальної мети - наживи як обов'язкового елементу диспозиції досліджуваної статті. Окремо приділено увагу особливостям кваліфікації повторності злочинів та питанням призначення покарання за результатами огляду судової практики. Проведено аналіз судової практики в частині кваліфікації створення або утримання місць розпусти і звідництва.

Структура статті складається зі вступної частини, в якій визначено: актуальність теми, попередні наукові розробки, проведені за напрямом статті, мету дослідження та проблематику, викладення основного матеріалу, присвяченого об’єктивним, суб'єктивним ознакам злочину та особливостям його кваліфікації. Також приділено увагу питомій вазі кримінальних правопорушень за ст. 302 КК України, розрахунки якої здійснені від загальної кількості злочинів проти громадського порядку та моральності за останні п'ять років та порівняльній характеристиці чинної норми КК України та норм кодексів зарубіжних країн у частині відповідальності за досліджуваний злочин. На підставі проведеного дослідження вироблено авторські висновки та визначені шляхи подальших наукових розробок за цим напрямом.

\section{ЛIТЕРАТУРА}

1. Александров Ю.В., Клименко В.А. Кримінальне право України: Заг. Частина : підручник для студентів вищих навчальних закладів. Київ : МАУП, 2004. $328 \mathrm{c.}$

2. Вирок Довгинцівського районного суду м. Кривого Рогу Дніпропетровської області від 06.09.2019. Справа № 211/4106/18. URL: http://reyestr.court.gov.ua/Review/84096132 (дата звернення: 21.05.2020).

3. Вирок Дружківського міського суду Донецької області від 06 вересня 2018 року. ЄУН 229/3234/17. Провадження 1-кп/229/130/2018. URL: http://reyestr.court.gov.ua/Review/76365933 (дата звернення: 20.05.2020). 
4. Вирок Шевченківського районного суду м. Запоріжжя від 05.04.2019 p. Справа № 336/3804/16-к. Провадження № 1-кп/336/13/2019. URL: http://reyestr.court.gov.ua/Review/80961270 (дата звернення: 20.05.2020).

5. Вирок Шевченківського районного суду м. Києва від 20.02.2019 року. Справа № 761/21298/18. Провадження № 1-кп/761/1306/2019. URL: http://reyestr.court.gov.ua/Review/79986540 (дата звернення: 20.05.2020).

6. Конвенція про боротьбу 3 торгівлею людьми i 3 експлуатацією проституції третіми особами : Міжнародний документ від 02.12.1949. URL: https://zakon.rada.gov.ua/laws/show/995_162 (дата звернення: 05.05.2020).

7. Кримінальне право України :- Особлива частина : підручник / Ю.В. Баулін та ін. ; за ред. В.В. Сташиса, В.Я. Тація. Харків : Право, 2010. $608 \mathrm{c}$.

8. Кримінальний кодекс Республіки Казахстан : Закон Республіки Казахстан від 03.07.2014 p. № 226-V. Дата оновлення: 04.05.2020 p. URL: https://online.zakon.kz/document/?doc_id=31575252 (дата звернення: 12.05.2020).

9. Кримінальний кодекс Російської Федерації : Закон Російської Федерації від 13.06.1996 р. № 63-ФЗ. Дата оновлення: 12.04.2020 p. URL: http://www.consultant.ru/document/cons_doc_LAW_10699/ (дата звернення: 10.05.2020).

10. Нєбитов А.А. Кримінальна відповідальність за створення або утримання місць розпусти і звідництво: актуальні проблеми теорії i практики. Боротьба з організованою злочинністю $i$ корупцією (теорія $i$ практика). 2014. № 1 (32). С. 95-98.

11. Орлеан А. Кримінально-правова охорона людини від сексуальної експлуатації. Вісник Наџіональної академії прокуратури України. 2012. № 2. С. 5-54.

12. Словник української мови : в 11 томах / ред. Г.М. Гнатюк, Т.К. Черторизька. Київ : Наукова думка, 1972. Том 3.744 с.

13. Статистичні дані Генеральної прокуратури України про кримінальні правопорушення по державі за 2015 рік. URL: https://old.gp.gov.ua/ua/stst2011.html?dir_id=112169\&libid=100820\# (дата звернення: 06.05.2020).

14. Статистичні дані Генеральної прокуратури України про кримінальні правопорушення по державі за 2016 рік. URL: https://old.gp.gov.ua/ua/stst2011.html?dir_id=112661\&libid=100820 (дата звернення: 07.05.2020).

15. Статистичні дані Генеральної прокуратури України про кримінальні правопорушення по державі за 2017 рік. URL: 
https://old.gp.gov.ua/ua/stst2011.html?dir_id=113281\&libid=100820 (дата звернення: 07.05.2020).

16. Статистичні дані Генеральної прокуратури України про кримінальні правопорушення по державі за 2018 рік. URL: https://old.gp.gov.ua/ua/stst2011.html?dir_id=113653\&libid=100820 (дата звернення: 08.05.2020).

17. Статистичні дані Генеральної прокуратури України про кримінальні правопорушення по державі за 2019 рік. URL: https://old.gp.gov.ua/ua/stst2011.html?dir_id=113897\&libid=100820 （дата звернення: 08.05.2020).

\section{Information about authors:} Skok O. S.,

$\mathrm{Ph}$. D. of Law Sciences, Associate Professor at the Department of Criminal-legal Disciplines Dnipropetrovsk State University of Internal Affairs 26, Gagarin Avenue, Dnipro, 49005, Ukraine Shevchenko T. V., Senior Lecturer at the Department of Criminal-legal Disciplines

Dnipropetrovsk State University of Internal Affairs 26, Gagarin Avenue, Dnipro, 49005, Ukraine 